\title{
КОНЦЕНТРАЦІЯ ГЛЮКОЗИ ТА ІНСУЛІНУ У ПАЦІЄНТОК ЗІ СИНДРОМОМ ПОЛІКІСТОЗНИХ ЯЄЧНИКІВ
}

ТОМАШ МІЛЄВІЧ ${ }^{1}$, ЮЗЕФ КШИСЕК', МАГДАЛЕНА КШИЧКОВСЬКАСЕНДРАКОВСЬКА ${ }^{1}$, МАГДАЛЕНА СПАЛКОВСЬКА АННА ПЕЛКА БАРБАРА ВАСИЛЬ², МАГДАЛЕНА ПУЛЬКА ${ }^{2}$ ЗЛАТА ЧАЙКІВСЬКА², ЄВА СТОХМАЛЬ ${ }^{3}$, ЕЛІНА ЧАЙКІВСЬКА ${ }^{4}$

${ }^{1}$ Клініка гінекологічної

ендокринології Ягеллонського університету, Краків, Польща

${ }^{2}$ Студентське наукове товариство Ягеллонського університету, Краків, Польща ${ }^{3}$ Кафредра і клініка ендокринології Ягеллонського університету, Краків, Польща ${ }^{4}$ Кафедра акушерства,

гінекології та перинатології Львівського державного медичного університету ім. Данила Галицького
Сндром полікістозних яєчників (СПКЯ) - це зивають синдромом Штейна - Левенталя. Діагностується у 4,7-10\% жінок дітородного віку. Хоча СПКЯ пов'язаний із появою багатьох характерних симптомів, діагноз не завжди $є$ однозначним і створює багато труднощів. Виявлення захворювання базується на підтвердженні двох із трьох перелічених симптомів: порушення менструального циклу, пов'язаного з відсутністю овуляції; клінічні і/або біохімічні ознаки надлишку андрогенів; характерна морфологічна картина яєчників при УЗД [2, 13].

Сучасні знання не дають змоги окреслити етіологію синдрому, проте з'являється чимало відомостей, які свідчать про вплив резистентності інсулінового рецептора і гіперінсулінізму. Це доводить той факт, що у пацієнток зі СПКЯ ризик розвитку цукрового діабету (ЦД) 2-го типу в 3-7 разів вищий порівняно з популяцією жінок без цього синдрому $[19,20]$. Крім того, у пацієнток зі СПКЯ перехід нетолерантності до глюкози у ЦД 2-го типу у 5-10 разів вищий ніж у групі здорових жінок $[9,20]$. В одній із праць описано, що в італійській популяції виявлено від 2 до 4 (залежно від використаних діагностичних критеріїв СПКЯ) разів вищу частоту появи метаболічного синдрому в осіб зі СПКЯ порівняно з жінками без цього синдрому [3, 4]. У той же час після збору сімейного анамнезу щодо наявності ЦД 2-го типу у пацієнток зі СПКЯ зафіксовано частішу появу цього захворювання серед рідних першої гермінальної лінії [8, 17]. У зв'язку з цим рекомендувалося проводити рандомізовані дослідження у жінок зі СПКЯ кожні 2-3 роки з метою виявлення метаболічного синдрому [3, 4]. У свою чергу, відповідно до рекомендацій Польського діабетологічного товариства від 2006 р., у кожної пацієнтки зі СПКЯ слід визначати рівень глікемії у зв'язку з підвищеним ризиком розвитку ЦД 2-го типу. У вагітних зі СПКЯ також спостерігається підвищена частота розвитку ЦД у порівнянні з тими, у кого цей синдром відсутній $[14,18]$.

Ще одним доказом на користь значення інсуліну і резистентності його рецепторів у жінок зі СПКЯ є дослідження, що підтверджують підвищену концентрацію проінсуліну і посилення його метаболізму у таких пацієнток [25]. Це може бути пов'язано з надмірною потребою інсуліну і скороченням внаслідок цього тривалості його синтезу та дозрівання в $\beta$-клітинах островків Лангерганса [15]. Виявлено, що інсулінорезистентність при СПКЯ має пострецепторний характер, який проявляється одразу після поєднання інсуліну з його рецептором [5-7]. Він стосується порушення процесу приєднання фросфорної групи (фосфрориляції) тирозинкінази або кількості і ролі транспортерів глюкози GLUT-4 [10, 26].

Підвищений рівень інсуліну в крові призводить до підсилення продукції андрогенів яєчниками, внаслідок чого відбувається надмірна гіперплазія клітин шкіри, що зумовлює розвиток чорного акантозу (acanthosis nigricans), а також до зменшення продукції гепатоцитарних інсулінозалежних білків, особливо секс-стероїдзв'язуючого глобуліну (ССЗГ) [21, 22].

Крім того, значний вплив на концентрацію інсуліну має рівень ожиріння у жінок зі СПКЯ. Доведено, що у пацієнток із цим синдромом і нормальною масою тіла наявна вища концентрація інсуліну у крові після прийому їжі. У дослідженнях Holteand et al. (1998), Кшичковської-Сендраковської та співавт. (2006), а також Ovesen et al. (1993) виявлено зниження тканинного використання глюкози тільки у пацієнток з надмірною масою тіла і СПКЯ [11, 16, 24]. Інсулінорезистентність, що проявляється незалежно від маси тіла в осіб зі СПКЯ, має місце в основному в м'язах і жировій тканині, однак не стосується ані печінки, ані яєчників.

Мета нашого дослідження полягала в оцінці концентрації глюкози та інсуліну у сироватці крові за допомогою перорального глюкозотолерантного тесту (ПГТТ) у пацієнток зі СПКЯ (група А) порівняно з жінками без цього синдрому (група В).

\section{МАТЕРІАЛ I МЕТОДИ ДОСЛІДЖЕННЯ}

У дослідженні взяли участь 40 пацієнток, яких було розподілено на дві групи. Перша група (А) складалася з 15 жінок, у яких відповідно до Роттердамських критеріїв був підтверджений СПКЯ, а друга група (В) - 325 жінок без цього синдрому.

Кожній із пацієнток був проведений ПГТТ (із застосуванням 75 г глюкози), під час якого на 60-й і 120-й хвилині вимірювали рівень глюкози та інсуліну між 5-м і 8-м днем менструального циклу. Пацієнтки не вживали їжі щонайменше упродовж 12 год до першого забору крові. Перед проведенням тесту принаймні за 3 дні вони вели нормальний спосіб життя: не обмежували себе в їжі і не змінювали своєї дієти та фрізичного навантаження. У день перед обстеженням жінки не вживали кави та алкоголю. 


\begin{tabular}{|c|c|}
\hline Параметри & Середнє значення \\
\hline IMT, кг/M² & $20,6 \pm 8,9$ \\
\hline ЛГ, МО/л & $11,7 \pm 12,7$ \\
\hline ФСГ, МО/л & $6,3 \pm 3,0$ \\
\hline Тестостерон, нмоль/л & $2,1 \pm 0,4$ \\
\hline Естрадіол, пмоль/л & $240,6 \pm 121,6$ \\
\hline ДГЕА-С, мкмоль/л & $11,2 \pm 3,1$ \\
\hline ССЗГ, нмоль/л & $44,7 \pm 27,4$ \\
\hline \multicolumn{2}{|c|}{$\begin{array}{l}3 \text { метою визначення індексу маси тіла (IMT) } \\
\text { були виміряні зріст пацієнток і маса тіла. } \\
\text { Рівень фролікулостимулюючого (ФСГ), лю- } \\
\text { теїнізуючого (ЛГ), тиреотропного (ТТГ) гор- } \\
\text { монів, тестостерону, дегідроепіандростерон- } \\
\text { сульфрату (ДГЕА-С) та естрадіолу визначали } \\
\text { за допомогою реактивів ECLIA Roche. За рі- }\end{array}$} \\
\hline
\end{tabular}

пою. Натомість натще і на 60-й хвилині ПГТТ ми не виявили вагомих відмінностей у глікемії між групами. Однак дослідження I. Jialal et al. (1987) вказують на підвищену концентрацію глюкози під час ПГТТ у пацієнток зі СПКЯ порівняно з популяцією жінок без СПКЯ [12]. Згідно з нашими дослідженнями, рівень інсулінемії у жінок групи А був значно вищий на 120-й
Група B ( $=25)$

\begin{tabular}{|c|c|c|}
\hline ереднє значення & Діапазон & $\mathbf{p}$ \\
\hline $20,5 \pm 8,6$ & $17,6-32,4$ & NS \\
\hline $9,0 \pm 4,7$ & $4,1-21,4$ & NS \\
\hline $7,1 \pm 6,3$ & $4,1-8,4$ & NS \\
\hline $1,1 \pm 0,4$ & $0,4-1,6$ & $<0,001$ \\
\hline $255,2 \pm 176,5$ & $64,9-833,4$ & NS \\
\hline $7,2 \pm 2,2$ & $2,5-11,8$ & $<0,02$ \\
\hline $59,9 \pm 21,7$ & $27,7-101,5$ & NS \\
\hline
\end{tabular}

ТАБлИЦЯ 1

ХАРАКТЕРИСТИКИ ПАЦІЕНТОК NS - різниця статИстично не достовірна

\begin{tabular}{|l|r|}
\hline \multicolumn{1}{|c|}{ Параметр } & Середнє значе \\
\hline Глікемія натще, ммоль/л & $4,9 \pm 0,7$ \\
\hline Глікемія на 60-й хвилині ПГТТ, ммоль/л & $5,9 \pm 1,9$ \\
\hline Глікемія на 120-й хвилині ПГТТ, ммоль/л & $5,5 \pm 1,0$ \\
\hline Інсулінемія натще, МО/л & $13,9 \pm 12,9$ \\
\hline Інсулінемія на 60-й хвилині ПГТТ, МО/л & $76,0 \pm 57,2$ \\
\hline Інсулінемія на 120-й хвилині ПГТТ, МО/л & $75,4 \pm 93,9$ \\
\hline
\end{tabular}

\section{РЕЗУЛЬТАТИ ДОСЛІДЖЕННЯ}

В обох популяціях (групах А та В) не виявлено різниці у значенні ІМТ $(20,6 \pm 8,9$ та 20,5 \pm 8,6 кг/м² відповідно). Рівень ДГЕА-С у сироватці крові був вищий у групі пацієнток зі СПКЯ порівняно із пацієнтками без цього синдрому (11,2 \pm 3,1 і з 7,22, \pm 2 мкмоль/л відповідно). Рівень тестостерону був вищий у пацієнток групи А порівняно з жінками групи В $(2,1 \pm 0,4$ і 1,1 \pm 0,4 нмоль/л відповідно), однак не зафіксовано вагомої різниці в концентрації естрадіолу і ССЗГ (табл. 1).

Середній рівень глюкози у сироватці крові під час ПГТТ був приблизно однаковим в обох групах. Разом із тим середня концентрація інсуліну натще і під час проведення тесту була вищою у групі пацієнток зі СПКЯ, досягаючи статистичної значущості на 120-й хвилині тесту $(75,4 \pm 93,9$ порівняно з 43,9 \pm 31,4 MO/л, p < 0,02) (табл. 2).

\section{ОБГОВОРЕННЯ}

На основі отриманих результатів можна припустити існування резистентності інсулінових рецепторів у 15 жінок зі СПКЯ (група А). При цьому за рівнем IMT вони не відрізнялися від контрольної групи (група В).

У популяції обстежених жінок зі СПКя глікемія натще була незначно вищою на 120-й хвилині тесту порівняно $з$ контрольною гру- хвилині тесту порівняно з групою В. У свою чергу L.S. Arthur et al. (1999) виявили підвищення концентрації інсуліну на 60-й і 120-й хвилині ПГТТ [1], a O'Mearand et al. (1993) - вищу концентрацію інсуліну в сироватці крові натще у пацієнток зі СПКЯ та вищу добову концентрацію інсуліну порівняно із контрольною групою [23]. При цьому D.A. Ehrmann et al. $(1995,1999)$ сумнівалися у доцільності визначення рівня глюкози натще у пацієнток зі СПКЯ для підтвердження порушення толерантності глюкози [8, 9]. У свою чергу Е. Carmina $(2005,2006)$ вказував на відсутність доцільності визначення рівнів глюкози та інсуліну як діагностичного інструменту виявлення резистентності інсулінових рецепторів у жінок зі СПКЯ $[3,4]$.

У дослідженнях in vitro виявлено підвищену продукцію андрогенів у жінок після прийому інсуліну за рахунок того, що останній впливає на тека-клітини яєчника [1].

\section{ВИСНОВОК}

Отримані нами дані вказують на важливу роль інсуліну при визначенні етіології гормональних порушень у пацієнток зі СПКЯ. Однак слід нагадати, що за існуючими діагностичними критеріями СПКЯ визначення інсулінемії та інсулінорезистентності для підтвердження даного діагнозу не вимагається. 


\section{ЛІТЕРАТУРА:}

1. Arthur L.S., Selvakumar R., Seshadri M.S., Seshadri L.

«Hyperinsulinemia in polycystic ovary disease»; JReprod Med 1999; 44: 783-787.

\section{Banaszewska B., Pawelczyk L.}

„Zespół policystycznych jajników. Niepłodność i rozród wspomagany»; Wyd. Termedia, Poznań 2003, 63-71.

\section{Carmina E.}

«Metabolic syndrome in polycystic ovary syndrome»; Minerva Ginecol., 2006, 58,109-114.

\section{Carmina E., Orio F., Palomba S et al.}

"Ovarian size and blood flow in women with polycystic ovary syndrome and their correlations with endocrine parameters»; Fertil. Steril., 2005, 84, 413-419.

\section{Dunaif A.}

«Insulin resistance and the polycystic ovary syndrome: mechanism and implications for pathogenesis»; Endocrine Rev., 1997, 18, 774-800.

\section{Dunaif A., Segal K.,R., Futterwiet W. et al.}

«Profound peripheral insulin resistance, independent of obesity in polycystic ovary syndrome»; Diabetes, 1989, 38, 1165-1174

\section{Dunaif A., Wu X., Lee A. et al.}

«Defects in insulin receptor signalling in vivi in the polycystic ovary syndrome (PCOS)»; Am. J. Physiol.Endocrinol.Metab., 2001, 281, E392-E399.

\section{Ehrmann D.A., Barnes R.B., Rosenfield R.L. et al.}

«Prevalence of impaired glucose tolerance and diabetes in women with polycystic ovary syndrome»; Diabetes Care, 1999, 22, 141-146

\section{Ehrmann D.A., Sturis J., Byrne M.M. et al.}

«Insulin secretory defects in polycystic ovary syndrome»; J.Clin. Invest., 1995, 96, 520-527

\section{Grigorescu F., Flier J.S., Kahn C.R.}

«Defect in insulin receptor phosphorylation in erythryocytes and fibroblasts associated with severe insulin resistance»; J.Biol.Chem., 1984, 259, 15031511

\section{Holte J., Gennarelli G., Wilde L. et al.}

«High prevalence of polycystic ovaries and associated clinical, endocrine, and metabolic features in women with prevoius gestational diabetes mellitus"; J.Clin.Endocrinol.Metab, 1998, 83, 1143-1150.

\section{Jialal I., Naiker P., Reddi K., Moodley J., Joubert S.M.}

«Evidence for insulin resistance in nonobese patients with polycystic ovarian disease»; J. Clin. EndocrinolMetab 1987; 64: 1066-1069.

\section{Kinalska I.}

«Patofizjologia i następstwa kliniczne insulinooporności»; 2004.

\section{Kousta E., Cela E., Lawrence N. et al.}

«The prevalence of polycystic ovaries in women with a history of gestational diabetes»; Clin.Endo., 2000, 53, 501-507.

\section{Kowalska I., Kinalski M., Strączkowski M. et al.}

„Insulin, leptin, IGF-I and insulin-dependent protein concentrations after insulin-sensitizing therapy in obese women with polycystic ovary syndrome»: Eur.J.Endocrinol., 2001, 144, 509-515.

\section{Krzyczkowska-Sendrakowska M., Krzysiek J., Milewicz T. i} wsp.

Insulinooporność w relacji do masy ciała u kobiet z zespołem policystycznych jajników»; Gin.Pol., 2006, supl.1, 65.

\section{Legro R.S.}

«Type 2 diabetes and polycystic ovary syndrome»; Fertil. Steril., 2006, 86 suppl 1, 16-17.

\section{Legro R.S., Castracane V., Kauffman R.}

"Detecting insulin resistance in polycystic ovary syndrome: purposes and pitfalls»; Obstet. Gynecol. Surv., 2004, 59, 141-154

\section{Legro R.S., Finegood D., Dunaif A.}

«A fasting glucose to insulin ratio is a useful measure of insulin sensitivity in women with polycystic ovary syndrome»; J.Clin.Endocrinol.Metab., 1998, 83, 2694-2698

\section{Legro R.S., Kunselman A.R., Dodson W.C. et al.}

«Prevalence and predictors of risk for type 2 diabetes mellitus and impaired glucose tolerance in polycystic ovary syndrome. A prospective controlled study of 254 affected women»; J.Clin.Endocrinol.Metab., 1999, 84, 165-169.

\section{Milewicz T., Krzysiek J., Sztefko K. et al.}

«The high serum IGF-I level in polycystic ovary syndrome correlated both with serum insulin and androgenism»; IV European Congr. of Endocrinology, Sevilla, Spain, 9-13.05. 1998

22. Nestler J.E., Jakubowicz D.J., Evans W.S. et al.

«Effects of metformin on spontaneous and clomiphene-induced ovulation in the polycystic ovary syndrome»; N.Engl.J.Med., 1998, 338, 1876-1880.

\section{O'Meara M., Blackman J.D., Ehrmann D.A. et al.}

«Defects in beta-cell function in functional ovarian hyperandrogenism»; J.Clin.Endocrinol.Metab., 1993, 76, 1241-1247

24. Ovesen P., Moeller J., Ingerslev H.J. et al. «Normal basal and insulin-stimulated fuel metabolism in lean women with polycystic ovary syndrome»; J.Clin.Endocrinol.Metab., 1993, 77, 1636-1640.

\section{Panidis D., Macut D., Farmakiotis D. et al.}

«Indices of insulin sensitivity, beta cell function and serum proinsulin levels in the polycystic ovary syndrome»; Eur. J. Obstet. Gynecol. Reprod. Biol., 2006, 127, 99-105

\section{Rosenbaum D., Haber R., Dunaif A.}

GLUT4 glucose transporter abundance correlates with decreased insulin responsiveness in adipocytes from polycystic ovary syndrome (PCOS) women, independent of obesity and glucose intolerance. Am.J.Physiol., 1993, $264,197-202$ 